\title{
Twin Deficits and Feldstein-Horioka Puzzle in the Case Iran
}

\author{
*Farzane Bagheri1 ${ }^{1}$, Salma Keshtkaran², Fatemeh Daroghe Hazrati1 \\ ${ }^{1}$ Dariun Branch, Islamic Azad University, Dariun, Iran \\ 2Zand Institute of Higher Education-Shiraz, Iran \\ *farzane.bagheri64@gmail.com
}

\begin{abstract}
The main purpose of this study is to examine the relationship between budget deficit and current account deficit in Iran's economy through twin deficits and Feldstein-Horioka puzzle. To achieve this goal, Engel-Granger and seemingly unrelated regressions are used during "1971-2007". The results indicate that there exists a long run equilibrium link between budget deficit and current account deficit. There is a one-way causality relationship from the budget deficit toward the current account deficit .Testing the validity of the Feldstein-Horioka puzzle indicates a low level of international capital mobility for Iran.
\end{abstract}

Key words: Twin deficits, Budget deficit, Current account deficit, Feldstein-Horioka puzzle

\section{Introduction}

The purpose of this paper is to determine whether the budget deficit leads to an external deficit in Iran, i.e. whether there is evidence in favor of a twin deficit. In the 1980s, both the US external deficit and the budget deficit increased significantly. Because of this co-movement, several economists attributed a significant portion of the deterioration in the external balance to the emergence of record budget deficits. This causal relationship is known as the twin deficits hypothesis. As current account imbalances may hinder economic growth, this is a relevant topic for developing countries like Iran. There are some traditional theoretical explanations for the relation between the budget deficit (DEF) and the current account deficit (CAD). Firstly, and according to the Mundell-Fleming framework, an increase in the DEF induces an upward pressure on interest rates that, in turn, will cause capital inflows and an appreciation of the exchange rate, ultimately leading to an increase in the CAD (see for example, Kouassi, Mougou'e, \& Kymn, 2004). Secondly, according to the Keynesian absorption theory, an increase in the DEF would induce domestic absorption (an expansion of aggregated demand) and hence, an increase in imports, causing an increase or a worsening of the CAD. Furthermore, the twin-deficit issue is also related to the degree of international capital mobility and to the Feldstein and Horioka (1980) puzzle. If in fact savings and investments not are highly correlated, reflecting high capital mobility, then the DEF and the CAD are expected to move together. This traditional view is however challenged by the Ricardian equivalence hypothesis of Barro $(1974,1989)$. Ricardian equivalence states that, for a given expenditure path, the substitution of debt for taxes has no effect on aggregate demand nor on interest rates. As a result, it implies that a tax increase would reduce the budget deficit but would not alter the external deficit, since altering the means that the government uses to finance its expenditures does not affect private spending or national saving. The policy recommendations vary according to the type of relationship between the current account and the budget deficit. Yet, when Ricardian equivalence does not hold, there is scope for a causality relationship between the current account deficit and the budget deficit. In this regard, there are two other possibilities, besides the already discussed twin-deficit hypothesis that implies a positive and unidirectional Granger-causality running from the budget deficit to the current account deficit. Firstly, it is also possible to find a unidirectional causality running from the current account to the budget deficit. This is the case when deterioration in the current account results into diminished economic growth, and subsequently leads to deterioration in the budget balance. This reverse causation occurs also when the government is, in the terminology of Summers (1988), targeting the current account. That is, when the government has the goal of eliminating the external imbalances and uses the budget deficit as an instrument to achieve it. Secondly, a bi-directional causality might emerge between the two deficits. In this case, it does not suffice to cut the budget deficit to eliminate an external deficit. Attention should be devoted as well to the exchange rate policy, to the determination of interest rates and to export promotion policies. This paper examines the relationship between the budget deficit and the current account for the case of Iran, finding evidence in favor of twin deficit, and derives some policy implications. 


\section{Literature Review}

According to Feldstein and Horioka (1980) in a world of perfect capital mobility, the financing of domestic investment is not related to (nor constrained by) the amount of domestic saving. If in fact savings and investments are not correlated, reflecting high capital mobility, and Ricardian equivalence does not hold, the national account identity implies that the Government saving $\left(S^{g}\right)$ and the trade balance $(\mathrm{X}-\mathrm{M})$ move together, originating a twin deficit. Let us consider for example an increase in the budget deficit. If Ricardian equivalence does not hold, this decrease in the public saving is not compensated for by an increase in the private saving $\left(S^{p}\right)$, leading to a decrease in total domestic saving. Holding investment constant, this decrease in domestic saving implies a deterioration of the trade balance.

$$
(X-M)_{t}=S_{t}^{p}+S_{t}^{g}-I_{t}
$$

This identity motivates (Fidrmuc, 2003, p. 137) to test for a long run relationship among the current account (proxied by $\mathrm{X}-\mathrm{M}$ ), the budget deficit and total investment. The regression model proposed by Fidrmuc (2003) is, with variables (in small caps) expressed as a share of GDP:

$$
x_{t}-m_{t}=\gamma_{1}+\gamma_{2}\left(t_{t}-g_{t}\right)-\gamma_{3} i n v t_{t}+\varepsilon_{t}
$$

Where $(\mathrm{x}-\mathrm{m})$ is interpreted as the current account deficit, and $(\mathrm{t}-\mathrm{g})$ as the government budget deficit. The investment ratio is given by "invt". Due to the national account identity, an increase in investment leads, ceteris paribus, to a deterioration of the trade balance. Hence, a negative coefficient is expected for the coefficient on investment $\left(\gamma_{3} \prec 0\right)$. As follows from the discussion above, a positive coefficient is expected for the budget balance $\left(\gamma_{2} \succ 0\right)$ ), resulting into a twin deficit, if Ricardian equivalence does not hold. As a result, both an increase in the budget deficit and an increase in investment are expected to worsen the current account. Moreover, the coefficients of both variables should equal the unity if countries are perfectly integrated into the world economy, and both the budget deficit and (domestic) investment are financed in the world capital market. However, if the Feldstein-Horioka puzzle is present, the $\gamma_{3}$ coefficient is significantly lower than one. In this framework, a negative $\gamma_{2}$ coefficient leads to the rejection of the twin-deficit hypothesis. In economic literature, many researches focused on the relationship between current account deficit (CAD, hereafter) and budget deficit (DEF, hereafter). Fidrmuc (2003), using data from ten OECD countries, two emerging countries and six transition economies, confirmed the twin deficits hypothesis but with some noticeable differences between the result of the 1980s and those of the 1990s. He found several countries financed their investment mainly from domestic sources (savings). This feature confirmed earlier results on the so-called the FeldsteinHorioka puzzle. However, he found less evidence for the Feldstein-Horioka puzzle for the EU countries and for transition economies. This result indicates that EU integration has significantly increased the degree of openness in the participating economies. While most of the studies focused on the experience of the developed countries, little attention has been given to developing economies. Among a few exceptions are Islam's finding (1998), for Brazil, which is indicated the presence of bilateral causality between trade deficit and budget deficit. Alkswani (2000) provided empirical evidence on reverse causation between the two deficits for Saudi Arabia.

Marinheiro (2008) concluded for the presence of a (weak) long-run relationship between the budget deficit and the current account deficit and found evidence in favor of a reverse Granger-causality running from the CAD to the DEF. Furthermore, there was evidence in favor of a high degree of capital mobility (or financial integration). Baharumshah, Ismail and Lau (2005) examined the causal relation between current account deficit, budget deficit and investments in ASEAN countries. They concluded a high proportion of domestic investment was financed from international sources, which suggested that Feldstein - Horioka puzzle was less important in these emerging economies. Siddiqui (2010) investigated twin deficits in the case of Pakistan and found the long run relationship between budget deficit and trade deficit. This paper, unlike more other studies, is based on a principle. It investigates the relationship between the two deficits on petroleum economy where exports, government revenue, and income are closely linked with oil revenue. This paper analyzed the validity of the twin-deficit hypothesis for Iran. The validity of this hypothesis has strong policy implications, and is closely linked to the Feldstein-Horioka measure of capital mobility. The relationship between budget and current account deficits will be analyzed by using two complementary approaches: Seemingly Unrelated Regressions (SUR) and Granger causality tests. The 
structure of the paper is organized as follows. Section 2 addresses Literature Review. Section 3 presents the empirical results for Iran. The conclusion is presented in the last part.

\section{Method}

This section presents the empirical results for Iran. It starts by presenting the data. It then shows the results of testing for twin-deficits hypotheses.

The data: The data employed in this study are annual data (1971-2007). The main data source is the central bank of Islamic Republic of Iran dataset complemented with International Financial Statistics (IFS) of the International Monetary Fund (IMF). The external debt (GD) data is from the IFS. ${ }^{1}$

Unit root tests: The preliminary step of co-integration procedure is testing for the presence of a unit root in the series of interest. Thus, we first investigate the unit root properties of the data using ADF test statistics. The test results point uniformly to the presence of a unit root in the data, meaning that just the first difference of the series is stationary. In Perron's, view point (1989), in performing unit root tests, special care must be taken if it is suspected that structural change has occurred. Perron's structural change test has been done, due to revolution; war years in Iran during 1971-2007. As far as the structural change test was concerned, any of time series data did not have structural breaks; as a result, the integration degrees of all of them were I (1). Table 1 shows the ADF test result, for the variables in levels and in first differences.

Table 1: the ADF test

\begin{tabular}{lll}
\hline Variable & level & First differences \\
\hline DEF & -2.42 & -7.34 \\
CU & -0.72 & -3.62 \\
GC & -1.14 & -3.62 \\
GD & 3.01 & -3.72 \\
PG & -0.82 & -5.96 \\
YG & -2.77 & -7.15 \\
GDP & 2.08 & -3.63 \\
CAD & -2.74 & -5.43 \\
INVt & -2.2 & -5.06 \\
\hline
\end{tabular}

Source: Authors' calculations.

Notes: In ADF test, we assume that the data have a constant and a linear trend.

The lags for ADF test were chosen based on SIC.

The critical values at the 5\% significance level of (Hamilton, 1994) are (-2.93) and (-3.56) for the ADF test in the level and the first differences.

Twin deficits: We start our tests for Iran with the testing of the twin deficits hypothesis. Most studies centre their attention on the reaction of private consumption to government financing decisions. We estimate the link between budget deficits and both private consumption and the current account deficit by using the equations, namely the specification of Bernheim (1987).

$$
C U_{t}=\beta_{1}+\beta_{2} D E F_{t}+\beta_{3} G C_{t}+\beta_{4} G D_{t}+\beta_{5} Y G_{t}+\beta_{6} P G_{t}+e_{1 t}
$$

And

$$
C A D_{t}=\alpha_{1}+\alpha_{2} D E F_{t}+\alpha_{3} G C_{t}+\alpha_{4} G D_{t}+\alpha_{5} Y G_{t}+\alpha_{6} P G_{t}+e_{2 t}
$$

Where $\mathrm{CU}$ is private consumption,

DEF is the budget deficit,

GC is government consumption,

GD is external debt,

YG is GDP growth,

$\mathrm{PG}$ is population growth,

In addition, $\mathrm{CAD}$ is the current account deficit.

1- There is no external debt data for years 1978, 1984, 1985; therefore, "Spine Interpolation" method has been used for their calculation. 
Private consumption, budget deficit, government consumption, public debt and current account deficit are measured as ratios over GDP. Our focus is on the coefficients $\beta_{2}$ and $\alpha_{2}$. According to the twindeficits hypothesis, we should instead observe $\beta_{2} \succ 0$ and $\alpha_{2} \succ 0$ because consumption and the current account deficit should increase in response to an increase in the budget deficit. Our estimation strategy involves linking consumption behavior to budget balances, both of which are measured as shares of GDP, by controlling for changes in other fiscal variables (government consumption and public debt) and in other variables traditionally associated with consumption behavior (income growth and population growth). Systems (1) and (2) are estimated by the Seemingly Unrelated Regressions (SUR) procedure (since possible links may exist among individual regressions via contemporaneous correlation within equations (1) and (2).

\section{Results}

Table 2: SUR regressions

\begin{tabular}{lll}
\hline $\begin{array}{l}\text { Dependent Variables } \\
\text { Independent variables }\end{array}$ & Consumption/GDP & Current account deficit/ GDP \\
\hline Budget deficit & 3.81 & 0.28 \\
& $(2.3)$ & $(2.43)$ \\
Government consumption & 0.37 & -0.1 \\
& $(1.85)$ & $(-1.26)$ \\
Public debt & 17.32 & 0.89 \\
& $(9.07)$ & $(2.2)$ \\
Income growth & 0.17 & 0.32 \\
& $(2.26)$ & $(1.29)$ \\
Population growth & -20.29 & -7.57 \\
& $(-2.19)$ & $(-2.09)$ \\
\hline
\end{tabular}

Source: Authors' calculations. t- Statistics in ()

The coefficients of budget deficit on both the consumption and current account deficit model are positive. This finding supports the argument that consumption and current account deficit respond to fiscal policy changes. There is evidence in favor of a twin deficit.

Twin deficits and Feldstein-Horioka puzzle: This identity motivates (Fidrmuc, 2003) to test for a long run relationship among the current account (proxied by $\mathrm{X}-\mathrm{M}$ ), the budget deficit and total investment. The regression model proposed by Fidrmuc (2003) is, with variables (in small caps) expressed as a share of GDP:

$$
x_{t}-m_{t}=\gamma_{1}+\gamma_{2}\left(t_{t}-g_{t}\right)-\gamma_{3} i n v t_{t}+\varepsilon_{t}
$$

Where $(\mathrm{x}-\mathrm{m})$ is interpreted as the current account deficit, and $(\mathrm{t}-\mathrm{g})$ as the government budget deficit. The investment ratio is given by "invt". We have tested this specification with Iranian data, using the current account as dependent variable and the overall government budget deficit as the independent variable, both in the form of GDP ratios. The coefficients of both variables should equal the unity if countries are perfectly integrated into the world economy, and both the budget deficit and (domestic) investment are financed in the world capital market.

Table 3: Wald test result

\begin{tabular}{cll}
\hline F-statistic & Degrees of freedom & Prob. \\
\hline 83.33 & 2 & 0.032 \\
$H_{0}: \gamma_{2}=\gamma_{3}=1$ & & \\
\hline
\end{tabular}

Source: Authors' calculations.

Wald test results are shown in Table 3 and do not confirm that: $H_{0}: \gamma_{2}=\gamma_{3}=1$ Despite the increasing role of international financial markets, Iran is still financing their investment mainly from domestic sources (saving).

Granger Causality test: The Ganger causality tests help to determine the direction of causality between two deficits. The empirical result of Granger's test is presented in table 4. 
Table 4: Granger-causality test

\begin{tabular}{cll}
\hline Null hypothesis & F-statistic & Prob. \\
\hline DEF does not Granger causes CAD & 5.86 & 0.001 \\
CAD does not Granger causes DEF & 1.71 & 0.18 \\
\hline
\end{tabular}

Source: Authors' calculations.

Based on Table 4 the hypothesis that budget deficit does not Granger-cause current account deficit is rejected. This finding reconfirms twin deficits hypothesis in Iranian economy.

\section{Conclusion}

In this paper, we analyzed the relationship between budget deficit and current account deficit in Iran. The Ricardian equivalence argues that the budget and current account deficits are not correlated, whereas the Keynesian proposition confirms the existence of a positive relationship between the two deficits. Due to the basic source of income, in oil-based economy, in particular, Iran is the oil export revenue; this revenue affects the government revenues and the exports of goods and services. Considering the important role of oil revenue of the components of the trade accounts and the public budget, we expected a positive relationship among budget deficit and trade deficit and policy efforts should be directed primarily to the reduction of the budget deficit. To achieve our goal, SUR regressions and Granger causality tests were used. The results indicate that there exists a long run equilibrium link between budget deficit and current account deficit. Testing the validity of the Feldstein - Horioka puzzle indicates a low level of international capital mobility for Iran. Despite the increasing role of international financial markets, Iran is still financing their investment mainly from domestic sources (saving). However, the Granger-causality tests point: it is the budget deficit that Granger-cause the current account deficit (and not the other way round). As a result, the traditional twin-deficit hypothesis is accepted for Iran. It is suggested that the government should curtail its non-productive expenditures in order to reduce its budget deficit or try to increase tax revenue.

\section{References}

Alkswani, M. (2000).The Twin Deficits Phenomenon in Petroleum Economy: Evidence from Saudi Arabia. In Paper presented at the seventh annual conference, economic research forum (ERF).

Baharumshah, A. Z., Ismail, H. \& Lau, E. (2005). Twin Deficits Hypothesis and Capital Mobility: The ASEAN-5 Perspective. Journal Pengurusan, 29, 15-32.

Barro, R. (1974). Are Government Bonds Net Wealth? Journal of Political Economy, 82(6), 1095-1117.

Barro, R. (1989). The Ricardian Approach to Budget Deficits. Journal of Economic Perspectives, 3(2), 37-52.

Bernheim, B. (1987). Ricardian Equivalence an Evaluation of Theory and Evidence with Three Comments. NBER Macroeconomics Annual, 263-315.

Branson, W. (1993). World Interest Rate and the DM with Germany Unification. Paper Prepared for a Symposium in Honor of Heinz Konig, Manheim.

Feldstein, M. \& Horioka, C. (1980). Domestic saving and international capital flows. The Economic Journal, 90, 314-329.

Fidrmuc, J. (2003). The Feldstein-Horioka Puzzle and Twin Deficits in Selected Countries. Economics of Planning, 36, 135-152.

Islam, F. (1998). Brazil's Twin Deficits: An Empirical Examination. Atlantic Economic Journal, 26(2), 121-28.

Kim, K. (1995). On the Long-run Determinants of the US Trade Balance: A Comment. Journal of Post Keynesian Economics, 17, 447-55.

Kouassi, E., Mougou'e, M. \& Kymn, K. (2004). Causality Tests of the Relationship between the Twin Deficits. Empirical Economics, 29, 503-525.

Marinheiro, C. F. (2008). Ricardian Equivalence, Twin Deficits and the Feldestein-Horioka Puzzle in Egypt. Journal of Policy Modeling, 30, 1041-1056.

Perron, P. (1989). The great crash, the oil price shock, and the unit root hypothesis. Econometrica, 99, 1361-1401.

Siddiqui, M. (2010). Twin Deficits: An Empirical Analysis in the Case Pakistan. World Applied Sciences Journal, 8(11), 1398-1400.

Summers, L. (1988). Tax policy and international competitiveness. In Frenkel, J. A. (Ed.), International aspects of fiscal policies (NBER Conference Report), 349-375. 